\title{
Evidence-based Medicine: Alternative Medicine [Non-drug Medicine, CAM] versus Pharmacological Medicine
}

\section{Søren Ventegodt MD*}

MMedSci, EU-MSc-CAM, Director, Quality of Life Research Center, Research Clinic for Holistic Medicine, Nordic School of Holistic Medicine, Denmark

*Corresponding author: Søren Ventegodt MD, MMedSci, EU-MSc-CAM, Director, Quality of Life Research Center, Research Clinic for Holistic Medicine, Nordic School of Holistic Medicine, Denmark, Tel: +45 2066 67 66; E-mail: ventegodt@livskvalitet.org

Rec date: Mar 09, 2015; Acc date: Mar 11, 2015; Pub date: Mar 15, 2015

Copyright: (c) 2015 Ventegodt MD. This is an open-access article distributed under the terms of the Creative Commons Attribution License, which permits unrestricted use, distribution and reproduction in any medium, provided the original author and source are credited.

\section{Editorial}

Good scientific medicine has to major components: It has good theory and it has good clinical documentation.

Human beings are bio-psycho-social beings [1], while science are quite clear and simple when it comes to chemistry, physics and biology, it gets quite unclear and flimsy when it comes to psychology, and really messy when it comes to the social dimensions of man.

Good medicine theory is of cause interdisciplinary; it describes man as a bio-psycho-social being and disease as a disturbance in the wholeness, not in one of its parts. When you get sick, the symptoms are often in your body, but the cause is in your psyche; and if you explore your mental dimension you will find that it is highly dependent on you social reality.

If you look at the immune system its immunological defense power comes from the inner balance of the organism [2]; but this balance is hard to describe in scientific terms. We know that staying healthy is closely related to quality of life and happiness; you can say that happiness is the best medicine.

The biological and cellular order is highly sensitive to the state of mind of the person; but happiness goes even deeper: happiness goes to the roots of you being and stretches out to you most remote of your relationships. Your happiness vibrates though you whole existence. Happiness is a mystery in itself; there is no really good science about happiness, so to include happiness in the scientific theory of medicine has been and remains a real challenge. This work is simply not done yet. We have a lot of research to do here in the future! What we can say for sure is that a simple chemical model for life is totally inadequate to explain health, disease, bad thriving, and healing.

When it comes to scientific documentation of the clinical effect of medicine, we have even bigger problems, for what is a good test of clinical effect? We know by now that the randomized clinical trial [RCT], which everybody 30 years ago believed to be the final solution to the problem of how to test pharmacological medicine is so faulty and flawed that it cannot be taken as scientific documentation [3].

One problem is that the active placebo effect of poisonous drugs in the RCT-test as it is designed today turns all poisonous drugs tested by the method into effective medicine with exactly the specific action the test aims to explore $[3,4]$. This is a hopeless situation; the blinding is always broken by the toxic effects of the drugs and the pharmaceutical companies are producing "medicines" which only have toxic effects [3-5]. A number of Cochrane studies have recently documented that many of the drug-groups we are using are without significant beneficial effects but only poisonous $[5,6]$. Yet 100 million people or so are taking these drugs every day in the belief that they are helpful. And because of the active placebo they are helpful for a short while. But this is like peeing your pants to get heat: It only helps for a very short time; then it gets really annoying.

The consequence of the lack of a valid test method for pharmacological drugs has been devastating; According to leading experts in the Cochrane Collaboration millions of patients are getting poisoned with severe consequences for their health every year; and thousands of these patients are even dying from the poisoning [5]. Especially the psychiatric patients are burdened by the toxic effects of the drugs [6].

In evidence-based medicine you need to look at the quality of the scientific evidence. The best scientific evidence, like the meta analyses made by independent researchers i.e. the Cochrane reviews from the 3000 fairly independent physicians and researchers in the international Cochrane collaboration, has systematically shown that drugs are of little help for patients and almost always very harmful. Even the best of pharmacological medicines has surprisingly little effect; if you look at how many patients you need to treat for one being helped [the NNT number] it is normally 20 patients or more [7] [and often 100 or more for serious diseases like cancer and schizophrenia].

An NNT of 20 means that if a doctor gives such a drug to a patient, the likelihood for the patient to be helped is 0.05 , or only $5 \%$ ! If $\mathrm{NNT}=100$ only $1 \%$ of the patients are helped. And the people who are helped are most often NOT cured. They only have little less symptoms of the disease. So this is the situation of the pharmacological medicine we have today. At the same time, adverse effects are so normal that in average every patient will have a harmful effect from taking a drug [8]. Honestly it is not worth being a doctor with such poor results. Therefore many doctors burn out and loose the joy of work while they year after year see that their patients systematically are not improving.

So how is it with evidence-based CAM - alternative medicine, nondrug medicine - call it what you like? Today hundreds of metaanalyses and Cochrane reviews have shown that there are no significant side effects of non-drug medicine $[9,10]$ - with high-energy manipulations [chiropractic] as a rare exception. So you can safely go to any psychotherapist or bodyworker. Talk and touch therapy are just safe [10]. That is good to know.

But is CAM effective? Well, in general alternative medicine is not effective. Sorry. If you look at all that we do to help and cure, this broad spectrum of activities we call CAM are mostly NOT helpful. A number of scientific studies of prayers and positive thinking, diets, exercises, breathing exercises, yoga, meditation, art therapy, herbal medicine etc. have proven these types of CAM to be without significant positive effect for the patient [9]. Therefore, in general, CAM cures are not working.

With this said there are some types of talk and touch therapy that has been proven extremely effective. That is the methods that at the 
same time focus on 1] feelings and emotions including sexuality, 2] understanding and self-exploration including almost all types of selfinquiry, and 3] letting go of negative beliefs, attitudes, thoughts, philosophies, concepts etc - i.e. mind-work that empties your mind from all its mental contents and structures, and all our identifications [11-16].

Psychodynamic psychotherapy - i.e. talk therapy with focus on emotions and sexuality - have been proven extremely effective; 95\% have been helped and the help is often a cure [17-19]. Holistic medicine has recently in the USA been found extremely effective for cancer and coronary heart disease, with $80 \%$ of the patients or so helped within 3-6 month [20-22].These are amazing results.

Similar results have been found for a number of existentially oriented talk-and touch therapies $[23,24]$. Methods that combine talk and touch therapy to help the patient FEEL, UNDERSTAND and LET GO of negative beliefs have in general been found very effective, with amazing NNT numbers [1 or 2] and totally harmless. And the wonderful thing is that these methods seem to help a wide range of clinical conditions - almost all types of patients can be helped [25]. And these results are also found in meta analyses made by independent researchers.

See, this is good, evidence-based medicine. So we have after all come a long way in medicine.

The true problem of therapy is that some people just seem to have what it takes to become a therapist; they are good from the beginning of their practice even without education and training and they become only a little better as years go by Goleman [26]. And then there are the other group of therapist; the hardworking people with good intentions and little talent who will do much but accomplish little [27].

As we have not been able to teach these therapists how to become good therapist we obviously do not understand what it is that makes a good therapist.

In my experience it is about love. Some people simply love other people. These people can help almost everybody - because of their love as Buber points out [28]. They don't judge; they don't create a distance to their clients or patients. They just accept, acknowledge, care, and support whoever comes to them [29].

You cannot learn to love. If you do not love other people, you cannot be trained to do so. So in the end of the day, it all comes down to this simple thing: if you want to be a therapist ask if you love other people. If you don't and you still want to become therapist you might want to look at your motives. Being a bad therapist will not serve the world. But if you love other people just start today and open your practice. You will without doubt succeed.

Maybe you will wonder how these things fit together: That some methods seem to work, but that people cannot learn therapy. It seems that people with a talent for therapy are simply attracted to effective methods that focus on important issues like the meaning of life [30].

It takes a lot of love to work with people's feelings and sexuality; to help the sick and insane to explore there innermost secrets and to work patiently endless numbers of hours to help neurotic people to let go of untrue believes [27].

If you are troubled and in search for a good therapist yourself, don't waste your time reading science. Go and look for somebody who can love and serve you. Find a therapist with whom you have a good chemistry, a person you can feel you can trust and love yourself. If you can find such a person this is your best change for getting the help you need to change your life.

Everybody can heal, everybody can become happy. But to heal from a serious disease we need to change from a very deep place within ourselves. Facilitating this inner change that in the end will transform our whole being and experience of life is what all effective medicine is about [31].

\section{Acknowledgments}

The Danish Quality of Life Survey, Quality of Life Research Center and The Research Clinic for Holistic Medicine, Copenhagen, was from 1987 till today supported by grants from the 1991 Pharmacy Foundation, the Goodwill-fonden, the JL-Foundation, E. Danielsen and Wife's Foundation, Emmerick Meyer's Trust, the FrimodtHeineken Foundation, the Hede Nielsen Family Foundation, Petrus Andersens Fond, Wholesaler C.P. Frederiksens Study Trust, Else \& Mogens Wedell-Wedellsborg's Foundation and IMK Almene Fond. The research in quality of life and scientific complementary and holistic medicine was approved by the Copenhagen Scientific Ethical Committee under the numbers (KF)V. 100.1762-90, (KF)V. 100.2123/91, (KF)V. 01-502/93, (KF)V. 01-026/97, (KF)V. 01-162/97, (KF)V. 01-198/97 and further correspondence. We declare no conflict of interest.

\section{References}

1. Ventegodt S, Flensborg-Madsen T, Andersen NJ, Nielsen M, Mohammed $\mathrm{M}$, et al. (2005) Global quality of life (QOL), health and ability are primarily determined by our consciousness. Social Indicator Res 71: 87-122.

2. Ventegodt S, Omar H, Merrick J (2009) Quality of Life as Medicine: Interventions that Induce Salutogenesis. Social Indicator Res.

3. Ventegodt S, Andersen NJ, Brom B, Merrick J, Greydanus DE (2009) Evidence-based medicine: four fundamental problems with the randomized clinical trial (RCT) used to document chemical medicine. Int J Adolesc Med Health 21: 485-496.

4. Boutron I, Estellat C, Guittet L, Dechartres A, Sackett DL, et al. (2006) Methods of blinding in reports of randomized controlled trials assessing pharmacologic treatments: a systematic review. PLoS Med 3: e425.

5. Gøtzsche P (2013) Deadly Medicines and Organised Crime: How Big Pharma Has Corrupted Healthcare New York: Radcliffe.

6. Gøtzsche PC (2014) Psychiatry has gone astray. We would be much better off if we took away all psychotropic drugs from the market. The physicians are not able to handle them Politiken.

7. Smith R (2003)The drugs don't work. BMJ 327.

8. Ventegodt S, Merrick J (2010) Therapeutic value of treatments with pharmaceutical drugs. BMJ.

9. (2005) Committee on the Use of Complementary and Alternative Medicine by the American Public. Complementary and Alternative Medicine (CAM) in the United States. Washington DC National Academies Press.

10. Ventegodt S, Merrick J (2009) A Review of side effects and adverse events of non-drug medicine: Psychotherapy, mind-body medicine and clinical holistic medicine. J Complement Integr Med 6: 16.

11. Ventegodt S, Merrick J (2012) Textbook on Evidence-Based Holistic Mind-Body Medicine: Basic Philosophy and Ethics of Traditional Hippocratic Medicine. New York Nova Science.

12. Ventegodt S, Merrick J (2012) Textbook on Evidence-Based Holistic Mind-Body Medicine: Basic Principles of Healing in Traditional Hippocratic Medicine. New York: Nova Science. 
Citation: Ventegodt MD (2015) Evidence-based Medicine: Alternative Medicine [Non-drug Medicine, CAM] versus Pharmacological Medicine . Altern Integ Med 4: e116. doi:10.4172/2327-5162.1000e116

Page 3 of 3

13. Ventegodt S, Merrick J (2012) Textbook on Evidence-Based Holistic Mind-Body Medicine: Healing the mind in Traditional Hippocratic Medicine. New York: Nova Science.

14. Ventegodt S, Merrick J (2013) Textbook on Evidence-Based Holistic Mind-Body Medicine: Holistic Practice of Traditional Hippocratic Medicine. New York: Nova Science.

15. Ventegodt S, Merrick J (2013) Textbook on Evidence-Based Holistic Mind-Body Medicine: Research, Philosophy, Economy and Politics of Traditional Hippocratic Medicine. New York: Nova Science.

16. Ventegodt S, Merrick J (2013) Textbook on Evidence-Based Holistic Mind-Body Medicine: Sexology and Traditional Hippocratic Medicine. New York: Nova Science.

17. Leichsenring F, Rabung S, Leibing E (2004) The efficacy of short-term psychodynamic psychotherapy in specific psychiatric disorders: a metaanalysis. Arch Gen Psychiatry 61: 1208-1216.

18. Leichsenring F (2005) Are psychodynamic and psychoanalytic therapies effective?: A review of empirical data. Int J Psychoanal 86: 841-868.

19. Leichsenring F, Leibing E (2007) Psychodynamic psychotherapy: a systematic review of techniques, indications and empirical evidence. Psychol Psychother 80: 217-228.

20. Ornish D, Brown SE, Scherwitz LW, Billings JH, Armstrong WT, et al. (1990) Can lifestyle changes reverse coronary heart disease? The Lifestyle Heart Trial. Lancet 336: 129-133.

21. Ornish D, Scherwitz LW, Billings JH, Brown SE, Gould KL, et al. (1998) Intensive lifestyle changes for reversal of coronary heart disease. JAMA 280: 2001-2007.
22. Frattaroli J, Weidner G, Dnistrian AM, Kemp C, Daubenmier JJ, et al. (2008) Clinical events in prostate cancer lifestyle trial: results from two years of follow-up. Urology 72: 1319-1323.

23. Allmer C, Ventegodt S, Kandel I, Merrick J (2009) Positive effects, side effects, and adverse events of clinical holistic medicine. A review of Gerda Boyesen's nonpharmaceutical mind-body medicine at two centers in the United Kingdom and Germany. Int J Adolesc Med Health 21: 281-297.

24. Ventegodt S, Merrick J (2009) Meta-analysis of positive effects, side effects and adverse events of holistic mind-body medicine: experience from Denmark, Sweden, United Kingdom and Germany. Int J Adolesc Med Health 21: 441-456.

25. Ventegodt S, Andersen NJ, Kandel I, Merrick J (2009) Comparative analysis of cost-effectiveness of non-drug medicine (non-pharmaceutical holistic, complementary and alternative medicine/CAM) and biomedicine for all clinical conditions. Int J Disabil Hum Dev 8: 245-256.

26. Goleman D (1997) Healing emotions: Conversations with the Dalai Lama on the mindfulness, emotions, and health. Mind Life Inst.

27. Kierkegaard SA (1983) The sickness unto death. Princeton Univ Press.

28. Buber MI (1970) New York: Charles Scribner.

29. Maslow AH (1962) Toward a psychology of being, New York: Van Nostrand.

30. Frankl V (1985) Man's search for meaning. New York: Pocket Books.

31. Antonovsky A (1987) Unraveling the mystery of health. How people manage stress and stay well. San Francisco: Jossey-Bass. 